Article

\title{
Corporate Sustainability: It's Mine! Effect of Green Product Psychological Ownership on the Environmental Behavior and Performance of Employees
}

\author{
Tai-Wei Chang ${ }^{1, *}$, Kuo-Hsuan Wang ${ }^{2}$ and Yi-Hsiung Lin ${ }^{2,3}$ \\ 1 Graduate School of Resources Management and Decision Science, National Defense University, \\ Taipei 112, Taiwan \\ 2 Department of Business Administration, National Taipei University, New Taipei City 237, Taiwan; \\ kingwang@itri.org.tw (K.-H.W.); yhlin.e1@msa.hinet.net (Y.-H.L.) \\ 3 Management College, National Defense University, Taipei 112, Taiwan \\ * Correspondence: allain1105@yahoo.com.tw
}

Received: 14 November 2020; Accepted: 12 December 2020; Published: 15 December 2020

check for updates

\begin{abstract}
Green shared vision (GSV) has provided a research prototype for past green management research topics; however, few studies have examined the confusion related to environmental issues among employees. Therefore, to fill the aforementioned research gap, this study used psychological ownership theory and expectancy-valence theory to establish a research framework for GSV. This study explored the relationships of GSV with employee green confusion (EGC) and employee environmental performance (EEP) as well as the mediating effect of green product psychological ownership (GPPO) on these relationships. The research results indicate that GSV positively affects GPPO, EGC, and EEP. Moreover, GSV also influences behavior and performance through personal psychological processes. Thus, if an enterprise wishes to establish GSV, it must adopt a series of supporting measures, including improving members' GPPO, to effectively reduce EGC and improve EEP to realize the goal of sustainable development.
\end{abstract}

Keywords: green shared vision; psychological ownership theory; green product psychological ownership; employee green confusion; employee environmental performance

\section{Introduction}

Corporate strategies worldwide are affected by environmental management issues [1]. When enterprises support environmental protection and actively participate in environmental management, they not only pursue corporate values but also improve their image by complying with environmental regulations [2]. Enterprises should embrace the philosophy of sustainability with a creative mind in this environmentalistic age [3,4]. In general, shared visions are developed at the organizational, group, or individual levels to generate motivation for achieving transformation from a present status to a desirable end status [5]. When the organizational planner has a strong vision, the sustainable development of a company is promoted [6]. Obtaining a better understanding of the driving forces behind the phenomena might help new companies to integrate resources and enhance their corporate performance [7]. A corporate shared vision is a key factor affecting the competitive advantage of a corporation over other entities. Currently, sustainable development has become an important issue worldwide. The pursuit and achievement of sustainable development goals (SDGs) has become a trend for companies. Therefore, corporate sustainability has become a major topic. 
Corporate sustainability refers to decreasing the waste of natural resources (especially nonrenewable resources) to zero during enterprise operational activities to reduce the damage caused by corporate activities on society or the environment [8]. Corporate sustainability has become an indispensable strategy for many companies today [9-11]. Such strategies are gradually being integrated into company activities and culture, whether with respect to the corporate system (including operations), strategies, organizational systems, or stakeholders (internal and external as well as social and environmental) [12]. Corporate sustainability has become the basis of sustainable success [13]. When employees and organizations have different values, implementing a developed sustainability plan is difficult [14]. Employees are the core resource of an enterprise [15]. Employees play an important role in maintaining the competitive advantage of an organization. They also determine the performance of the organization [16]. A company's ability to achieve a competitive advantage is related to its ability to employ excellent talent [17].

Given the aforementioned information, employees play an important role when designing sustainable development strategies for an enterprise. The occurrence of employee green confusion (EGC) cannot be ruled out when employees promote green shared vision (GSV). However, studies on green confusion have not focused on the views of an enterprise's employees. Most of these studies have examined consumer orientation and have focused on the effects of greenwash on consumers, such as the effects of greenwash on green consumer confusion and green trust [18] as well as environmental and product perceptions [19]. Thus, employee orientation related to confusion in the field of corporate sustainability has been rarely discussed. To fill this research gap, the present study proposes a new concept called EGC. This study refers to the definition of Chen and Chang [18] to define EGC as the confusion of employees regarding the environmental characteristics of company products or services. The present study developed an integral framework of employee environmental performance (EEP). It also investigated the relationships of GSV with EGC and EEP as well as the mediating effects of green product psychological ownership (GPPO) on these relationships. Environmentalism is an important corporate issue today, and EEP is critical to corporate sustainability. This research enables a better understanding of the effects of a shared vision and various types of integration on corporate management.

Studies have rarely used a theoretical basis to explore the effect of organizational members' psychological processes on the organization's environmental management performance [1,20-26]. This study investigated the effect of GSV on GPPO, EGC, and EEP by focusing on company staff and using psychological ownership (PO) theory and expected price theory. We used the obtained findings to fill the research gap on EGC issues in corporate sustainability research. This study proposes a comprehensive conceptual structure to explore the effect of company members' psychological processes regarding the company's green issues on the company's green management performance. The integrated conceptual structure is displayed in Figure 1.

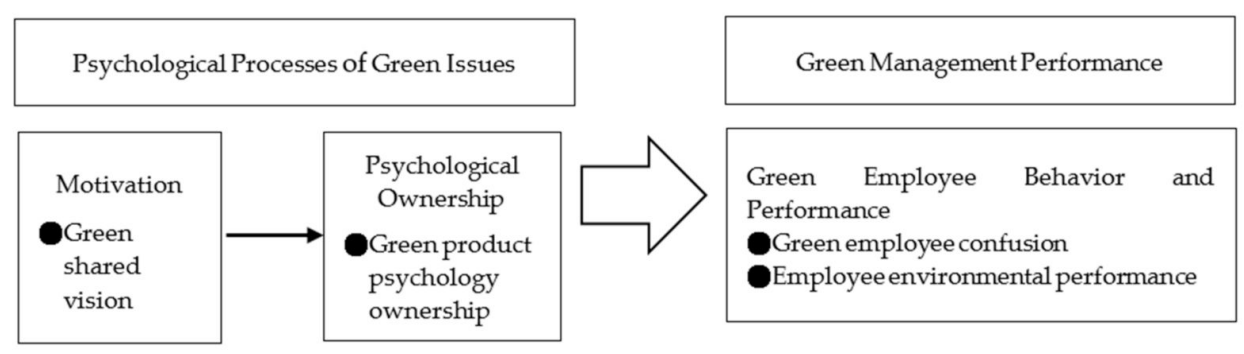

Figure 1. Integrated conceptual structure. 


\section{Literature Review and Hypothesis Development}

\subsection{Negative Effects of Green Shared Vision (GSV) on Employee Green Confusion (EGC)}

Given the global trend of concern for environmental issues, existing strict environmental regulations, and customers' perception of the environment, companies must develop suitable legal strategies to gain valuable resources $[27,28]$. A collective strategic direction can be encapsulated in a shared vision, which guides company members' actions according to a certain approach [29]. A shared vision can also be used to encourage corporate employees to exhibit excellent performance [30]. A shared vision is a key aspect of strategic management for a company because it indicates the unique objective, general direction, and practices of the company [31]. The method used by an organization to develop a shared vision has become the primary focus of environmental management research. The concept of GSV is defined on the basis of environmental friendliness and sustainable development [24]. Managers establish clear and common environmental goals for future organizational development, which enables the organization to supervise the green behavior and performance of employees as well as minimize EGC.

Staff confusion may occur when a company provides excessively similar, excessively complex, or an excessive amount of product or service information regarding SDGs. The larger the amount of information processed by an individual, the higher is their likelihood of experiencing information overload [32]. Information overload creates confusion [33], and EGC may affect a company's SDGs. This research refers to the definition of EGC provided by Chen and Chang [18], who stated that EGC refers to employees' inability to correctly understand the environmental characteristics of their company's products and services as well as the characteristics of its environmental policy during information processing. Therefore, companies must formulate a clear green common vision and effectively obtain employee recognition to encourage the green behavior and performance of employees $[24,34,35]$. GSV can encourage the green behavior and performance of employees, effectively develop employee recognition, and eliminate EGC. GSV is negatively related to EGC. Therefore, the following hypothesis is proposed:

Hypothesis 1 (H1). GSV is negatively associated with EGC.

\subsection{Positive Effects of Green Shared Vision (GSV) on Employee Environmental Performance (EEP)}

Currently, many companies are facing challenges caused by the rise of global environmental awareness, increasingly stringent environmental regulations, and increasing consumer environmental awareness. To ensure that valuable resources are obtained legally, an organization must formulate a suitable legal strategy $[27,28]$. A carefully planned and designed company vision facilitates employees' actions and decisions and inspires them to move toward a shared vision [36]. A shared vision is a common future goal set by an organization's manager for the development of the organization. It conveys the norms and beliefs of the company to members. A shared vision can motivate employees to perform [30] and exceed expectations related to their work performance [34].

When an organization proactively performs environmental actions, its long-term goals with respect to corporate greening are conveyed to its staff [37]. Environmental improvement performance depends on whether a shared vision exists between staff and managers, especially when environmental strategies require intensive staff engagement [38]. Above all, the process of combining corporate environmental performance and strategy is profoundly affected by the shared vision [39]. A shared vision can reduce the adverse effects caused by senior team members setting different goals and having conflicting views [40,41]. Moreover, such a vision can prevent the fragmentation of a team.

Team members must establish a shared vision, and continual interaction, practice, and reflection can improve team performance [42]. With regard to EEP, organization managers can influence green purchasing behavior [43], promote environmental market-oriented strategies [44], and encourage 
employees to have a responsible attitude toward environmental issues [45]. Organizations should always encourage members who possess good intentions, especially those who adopt a responsible attitude toward environmental issues. This step would enable employees to perform responsible actions when environmental problems arise.

Employees play an important role in promoting green management in an enterprise. Paillé and Meija-Morelos [46] defined EEP as the performance of employees' compliance with company norms, and their interaction and communication based on personal environmental knowledge to relevant stakeholders. Expectancy-valence theory is a cognitive motivation theory that connects the energy of an individual's motivation or willingness to strive for goals and expectations and obtain the expected value of the incentives to a specific purpose [47].

According to expectancy-valence theory, the choice, performance, and continuity of organization members' achievement behaviors are affected by expectations and values [48], which results in individuals investing increased efforts to obtain expected values [49]. When a company develops a suitable GSV, the GSV motivates employees to strive for goals and values that contribute to employee behavior. Related research has indicated that a shared vision is crucial for enhancing employee environmental behavior $[24,34,35,50]$. Consequently, the following hypothesis is proposed:

Hypothesis 2 (H2). GSV is positively associated with EEP.

\subsection{Effects of Green Product Psychological Ownership (GPPO)}

Psychological Ownership (PO) refers to the relationship between a person and an object that is closely connected with the self [51]. The concept of ownership is partially based on the research of consumer behavior regarding the extended self and possession [52,53]. Isaacs [54] indicated that the thoughts in a person's mind become a part of them. For an individual, when property is accepted in the mind, it becomes "mine" [55]. Legal ownership can provide an opportunity for individuals to assimilate themselves into a company and become part of it, which can enhance the emergence of ownership as a mental status [56]. Because ownership connects possessors to targets, when employees link work with emotion, their connection with the work becomes closer. Furthermore, positive attitudes and thoughts are generated to further promote work performance [57]. Ownership is a mental status experienced by humans in which people consider themselves to own a target (nonmaterial or material in nature) completely or partially [58]. According to Pierce et al. [58], PO refers to a personal sense of possession held by an individual for an immaterial or material object ("this is mine!"). Due to PO, an individual is willing to take responsibility or sacrifice for their organization [59].

For the sustainable development of an enterprise, the degree of PO of company members for their company's green products affects their behavior and attitude as well as the company's green management performance. GPPO occurs when a company member has a psychological sense of ownership for the company's green products, treats the products as subject matter, generates positive attitudes and thoughts, and is willing to engage in off-role behavior and take risks for this behavior such as dedication and sacrifice [35]. Therefore, for companies that are moving toward sustainable development, the degree of GPPO affects employees' behavior, attitudes, and organizational green management performance. Furthermore, when a company employee has strong GPPO, they would exhibit a positive attitude and positive ideas, be willing to take risks for the company, and make additional efforts and sacrifices [35].

\subsubsection{Positive Effects of Green Shared Vision (GSV) on Green Product Psychological Ownership (GPPO)}

Personal PO in organizations mainly originates from the four motivations of human needs: (1) Efficacy and effectance, (2) self-identity, (3) having a place, and (4) stimulation. Of these motivations, stimulation needs are incentives for PO. Efficacy and effectance indicate that individuals can successfully 
exercise control and appear to have a sense of ownership, which is used as a source of attaining satisfaction. Self-Identity represents the personal experience of biasing the subject matter, and as a part of self-extension, the most important thing is to own. Such holdings symbolize a kind of identity and are interpreted by others. Having a place refers to the need for personal space, which motivates individuals to control their surroundings and invest in them. Stimulation drives individuals to use, care about, and maintain objects. Thus, people are motivated to achieve stimulating needs and meet awakening requirements [58-61].

Many factors influence the formation of $\mathrm{PO}$. These factors influence not only the formation of $\mathrm{PO}$ and work characteristics but also the company culture, attitude of high-level managers, company's goals and vision, and reputation of the company [62]. A common vision conveys an organization's members' common goals and ambitions for the organization $[29,63]$. Moreover, it represents the organization's vision, mission, and core values $[64,65]$. Thus, when a company promotes sustainable development and formulates a GSV, this expresses to employees the goal and value of their efforts and strengthens their personal ownership and PO of the target green product. Chiu et al. [62] proposed that a company's goals and vision affect PO. Moreover, according to Chang [35], GSV contributes to GPPO. Therefore, we propose the following hypothesis:

Hypothesis 3 (H3). GSV is positively associated with GPPO.

2.3.2. Effect of Green Product Psychological Ownership (GPPO) on Employee Green Confusion (EGC) and Employee Environmental Performance (EEP)

PO affects individuals' attitudes, motivations, and behaviors. Furthermore, PO causes a person to exhibit a stance, sense of responsibility, and self-concept beyond the norms [66]. When an organization's members have PO for their organization, they tend to exhibit more responsibility for their roles, take greater care of the organization, and adopt a protective attitude toward the organization [67]. Moreover, they may be willing to take risks or make personal sacrifices for the organization [59] and the subject matter of PO [59]. When members of an organization have PO for a certain subject matter, they may exhibit positive attitudes toward the organization [68]. Research has indicated that $\mathrm{PO}$ is an important predictor of the status of members of organizations $[56,58,66,69,70]$. Studies have indicated that factors such as the work performance and satisfaction of work can be predicted by organization-based $\mathrm{PO}[58,59,71,72]$.

The PO of green products can predict individuals' organizational citizenship behavior for the environment [35]. When PO is assigned to a certain subject matter, employees tend to regard it as a social entity, be psychologically related to it, be willing to take risks for it, and generate positive attitudes and behaviors toward it. In general, according to PO theory, GPPO refers to the PO generated by employees of a company for its green products when they regard the products as a subject matter. GPPO enables a company's employees to exhibit positive attitudes and behaviors, and this contributes to organizational performance and encourages employees to actively search for information regarding company products, services, and related environmental policies that they did not understand initially. To maintain GPPO, employees become more willing to follow relevant environmental regulations and practices. Therefore, this study proposes the following hypotheses:

Hypothesis 4 (H4). GPPO is negatively associated with EGC.

Hypothesis $\mathbf{5}$ (H5). GPPO is positively associated with EEP.

\subsubsection{Mediating Effects of Green Product Psychological Ownership (GPPO)}

PO differs according to the motivation for possession. The feeling of possession is ubiquitous. Possession can be a tangible goal, an intangible goal, or a statutory but not legal form of ownership [73]. 
When the inner and psychological feelings possessed by an individual are integrated, and the members of the organization will be based on human instinct motivation, they may feel such ownership due to various factors in the organization and practice to further satisfy. In particular, when the target slowly becomes a part of the owner's psychological identification, $\mathrm{PO}$ is generated [58].

According to $\mathrm{PO}$ theory, an individual's PO of a certain subject matter originates from four demand motivations that include (1) efficacy and effectance, (2) self-identity, (3) having a place, and (4) stimulation [58-61]. The psychological history of $\mathrm{PO}$ as well as the personal positive behaviors and attitudes are based on interpretations of the subject of PO. According to the theoretical perspective of expectation motivation, an individual's positive performance and contribution are related to the desire to meet expectations $[48,49]$. Consequently, when the underlying motivation of an individual's PO meets the expected value, the individual would exhibit a highly positive behavior and attitude. Therefore, the following hypotheses are proposed:

Hypothesis 6a (H6a). The relationship between the exposure to EGC and GSV is mediated by GPPO.

Hypothesis $\mathbf{6 b} \mathbf{( H 6 b ) . ~ T h e ~ r e l a t i o n s h i p ~ b e t w e e n ~ t h e ~ e x p o s u r e ~ t o ~ E E P ~ a n d ~ G S V ~ i s ~ m e d i a t e d ~ b y ~ G P P O . ~}$

\subsection{Negative Effects of Employee Green Confusion (EGC) on Employee Environmental Performance (EEP)}

Companies are facing considerable pressure from relevant stakeholders, such as customers, business partners, and environmental organizations, to focus their policies on the environment [74] and develop, produce, and sell environmentally friendly products. Companies intending to achieve the goal of sustainable development may do well to formulate a GSV to promote all aspects of relevant environmental protection measures to create a green image of themselves [75-79]. Employees may experience information overload when an enterprise manager releases excessive information regarding the enterprise's environmental regulations, products, or services to quickly respond to requests from relevant stakeholders, such as customers, environmental organizations, and governments.

Mitchell, Walsh, and Yamin [32] indicated that people exhibit different levels of information cognition and digestion when they process information. When the amount of information increases, the likelihood of information overload also increases. The release of a large amount of information can cause confusion among employees [32,33] as well as make it difficult for employees to focus on the relevant environmental regulations promoted by the company and to interactively exchange environmental knowledge with relevant stakeholders. The aforementioned phenomenon of employee confusion is called EGC. When EGC occurs, employees' interactions with their organization's relevant norms and stakeholders are affected. Therefore, we propose the following hypothesis:

Hypothesis 7 (H7). EGC is negatively associated with EEP.

The research framework is illustrated in Figure 2. 


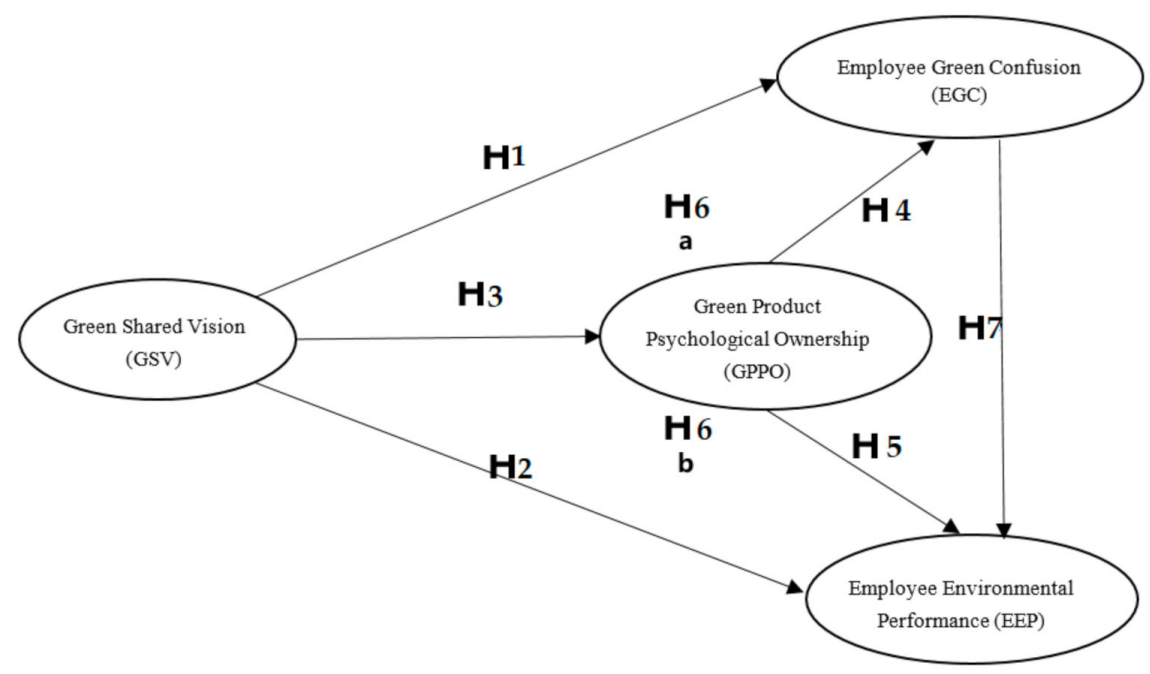

Figure 2. Research framework.

\section{Methodology and Measurement}

\subsection{Data Collection and Sample}

To verify the aforementioned hypotheses in the Taiwan production industry, a questionnaire survey was conducted. The study participants were staff members who worked in the information services, electronics, components manufacturing, computer and peripheral products, health care and biotech, communication equipment manufacturing, electronic products and components, equipment and machinery manufacturing, and software industries in Taiwan. The questionnaire survey sample was randomly selected from the "Business Directory of Taiwan." The participants were leaders or managers of the manufacturing, research and development, environment, or marketing departments or members of environmental product development projects. To ensure a high degree of content validity in this research, two rounds of pretests were conducted.

Respondents from different industries and sectors were recruited in this study because such recruitment reduces common method variance problems. To effectively improve the response rate, reliability, and validity of the questionnaire, before the questionnaire was issued, we contacted the relevant companies by phone to determine whether they provided green products or related services and confirmed whether green products were their primary revenue source. We provided gifts to the respondents after they filled the questionnaire. On the first page of the questionnaire, the research objectives were explained, and informed consent was requested from the participants. The participants were then informed that the green products or related services provided by their company were the evaluation targets of the company's GSV, EGC, EEP, and GPPO. We issued 750 formal questionnaires and obtained 475 valid questionnaires. Thus, the effective response rate was $63.33 \%$. In this study, in order to effectively reduce the possible factors that MacKenzie and Podsakoff [80] pointed out that are likely to cause CMV, we can hide the respondent information, the design purpose of the item, and randomly sort the items when designing the questionnaire. Furthermore, as suggested by Cacioppo and Petty [81], the semantics and words used in the design of the questionnaire are closer to the background of respondents. This can improve the entire questionnaire design, and we can survey people in different industries or units. Afterwards, the CMV test was conducted through Harman's one-factor test. The result indicated that the load of the first factor was $28.319 \%$, which met the standard value below $50 \%$. As a result, there was no serious CMV problem. 


\subsection{Measurements}

This research framework questionnaire contains four measurement dimensions (the scale presented in Appendix A), including GSV [25], GPPO [35], EGC [18,82], and EEP [46], using a 7-point Likert scale. While this research questionnaire refers to the scale developed by related scholars, there may still be research biases. This research is further verified through exploratory factor analysis, principal component analysis, and orthogonal rotation with varimax. The verification result shows that Bartlett's test of sphericity and the Kaiser-Meyer-Olkin (KMO) value all as stated by standard value [83] is suitable for exploratory factor analysis, with 17 items and 4 components. The component names are the same as the original construct, namely GSV, GPPO, EGC, and EEP (Table 1). Nunnally and Bernstein [84] suggested that the standard value of correlation coefficient (Cronbach's $\alpha$ ) should be more than 0.7 and each aspect meets the standard value. Consequently, the questionnaire of this research has good reliability.

Table 1. Results for the KMO value, Bartlett's test, and rotated component matrix.

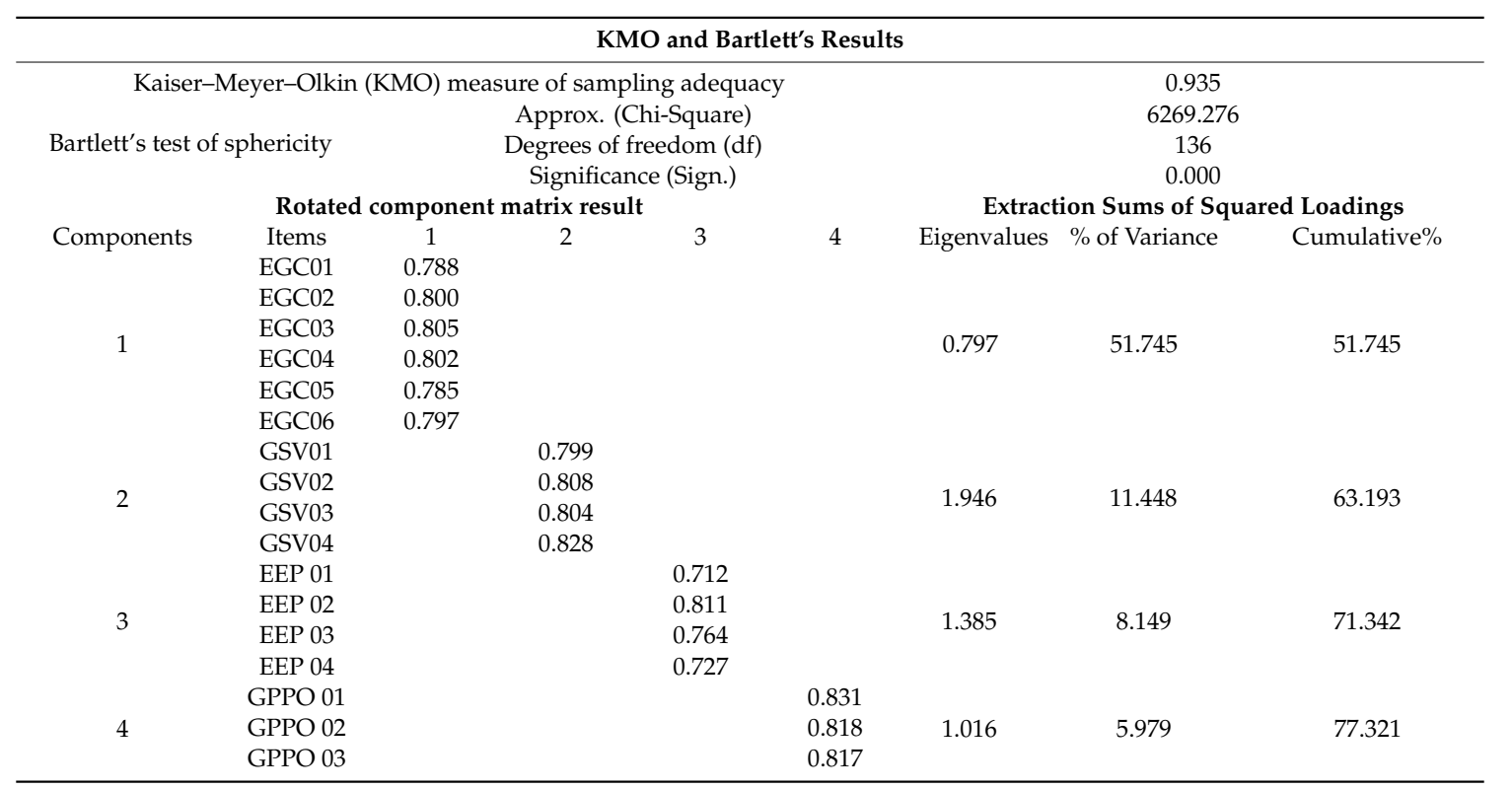

Notes: (1) GSV = green shared vision; GPPO = green product psychological ownership; EGC = employee green confusion; and EEP = employee environmental performance. (2) Extraction method: principal component analysis and rotation method: varimax with Kaiser normalization.

\section{Empirical Results}

\subsection{Measurement Model Results}

The standard deviations, means, and positive correlations of the constructs considered in this study are presented in Table 2. EGC was significantly negatively correlated with GSV, GPPO, and EEP, whereas the other constructs were significantly positively correlated.

Table 2. Means, standard deviations, and correlations of the constructs considered in this study.

\begin{tabular}{ccccccc}
\hline Constructs & Mean & Standard Deviation & A & B & C & D \\
\hline A. GSV & 4.79 & 1.03 & $(0.829)$ & & & \\
B. GPPO & 5.11 & 0.862 & $0.366^{* *}$ & $(0.852)$ & & \\
C. EGC & 5.184 & 0.838 & $-0.602^{* *}$ & $-0.531^{* *}$ & $(0.858)$ & \\
D. EEP & 3.43 & 1.045 & $0.476^{* *}$ & $0.618^{* *}$ & $-0.605^{* *}$ & $(0.792)$ \\
\hline
\end{tabular}

Notes: (1) Diagonal elements are the square roots of the average variances extracted; $(2) * *: p<0.01 ;(3)$ $\mathrm{GSV}=$ green shared vision, GPPO = green product psychological ownership, EGC = employee green confusion, and EEP = employee environmental performance; and (4) $N=475$. 
The loadings $(\lambda)$ of all the items of the four constructs are presented in Table 3 . All the loadings were significant and exhibited suitable values in the measurement mode. The Cronbach's $\alpha$ can be used as an index for determining the reliability (the standard value is 0.7) [85]. We verified the Cronbach's $\alpha$ values according to the recommendations of researchers such as Williams and Hazer [86] and Anderson and Gerbing [87]. The Cronbach's $\alpha$ values of all the constructs were more than 0.7, as presented in Table 4. Therefore, the measurement reliability is consistent with an acceptable standard value. According to Fornell and Larcker [88], when the square root of the average variation extracted (AVE) of the facet is greater than the correlation coefficient of the model facet, it means that each variable has discriminative validity, as shown in Table 2. The AVE square roots of the models GSV, GPPO, EGC, and EEP in this study are greater than the correlation coefficient of all the constructs. Thus, sufficient discriminant validity existed between any two constructs in this research.

Table 3. Item loadings ( $\lambda$ ), Cronbach's $\alpha$ coefficients, and average variations extracted (AVEs) of the constructs.

\begin{tabular}{|c|c|c|c|c|c|c|c|}
\hline Constructs & Items & $\lambda$ & $\mathbf{R}^{2}$ & Cronbach's $\alpha$ & CR & AVE & $\sqrt{\mathrm{AVE}}$ \\
\hline \multirow{4}{*}{ GSV } & GSV01 & 0.748 & 0.559 & \multirow{4}{*}{0.897} & \multirow{4}{*}{0.898} & \multirow{4}{*}{0.688} & \multirow{4}{*}{0.829} \\
\hline & GSV02 & $0.765^{* * *}$ & 0.586 & & & & \\
\hline & GSV03 & $0.895^{* * *}$ & 0.802 & & & & \\
\hline & GSV04 & $0.898^{* * *}$ & 0.806 & & & & \\
\hline \multirow{3}{*}{ GPPO } & GPPO01 & 0.860 & 0.739 & \multirow{3}{*}{0.887} & \multirow{4}{*}{0.888} & \multirow{4}{*}{0.726} & \multirow{3}{*}{0.852} \\
\hline & GPPO02 & $0.882^{* * *}$ & 0.777 & & & & \\
\hline & GPPO03 & $0.813^{* * *}$ & 0.662 & & & & \\
\hline \multirow{6}{*}{ EGC } & EGC01 & 0.856 & 0.732 & \multirow{6}{*}{0.943} & & & \multirow{6}{*}{0.858} \\
\hline & EGC02 & $0.875^{* * *}$ & 0.766 & & \multirow{5}{*}{0.944} & \multirow{5}{*}{0.736} & \\
\hline & EGC03 & $0.881^{* * *}$ & 0.776 & & & & \\
\hline & EGC04 & $0.837^{* * *}$ & 0.701 & & & & \\
\hline & EGC05 & $0.839^{* * *}$ & 0.703 & & & & \\
\hline & EGC06 & $0.859 * * *$ & 0.739 & & & & \\
\hline \multirow{4}{*}{ EEP } & EEP01 & 0.787 & 0.620 & \multirow{4}{*}{0.869} & \multirow{4}{*}{0.871} & \multirow{4}{*}{0.628} & \multirow{4}{*}{0.792} \\
\hline & EEP02 & $0.810^{* * *}$ & 0.657 & & & & \\
\hline & ЕЕР03 & $0.818^{* * *}$ & 0.669 & & & & \\
\hline & EЕP04 & $0.753^{* * *}$ & 0.567 & & & & \\
\hline
\end{tabular}

Notes: (1) ***: $p<0.001$; (2) CR: Composite reliability; (3) AVE: Average variation extracted.

Table 4. Heterotrait-monotrait (HTMT) analysis of the study.

\begin{tabular}{cccc}
\hline Constructs & GPPO & EEP & EGC \\
\hline EEP & 0.704 & & \\
EGC & 0.581 & 0.670 & \\
GSV & 0.409 & 0.539 & 0.654 \\
\hline
\end{tabular}

Henseler, Ringle, and Sarstedt [89] pointed out that the effect of the original Fornell and Larcker [88] discriminant validity test may be overestimated. Hence, this study further uses average heterotrait-monotrait (HTMT) to calculate the correlation ratio between the four facets of EEP, EGC, GSV, and GPPO. The overall result shows that it meets the standard value (all less than 0.85 ), so this study has good discriminative validity (see Table 4). A construct's convergent validity is acceptable if its AVE is greater than 0.5. The AVEs of GSV, GPPO, EGC, and EEP were 0.688, 0.726, 0.736, and 0.628, respectively, which are greater than 0.5 . Thus, the constructs considered in this study had suitable convergent validity. Besides, Bagozzi and Yi [90] pointed out that the R-square of the observation variable is $>0.5$, which means that each observation variable is suitable for measuring each potential variable (Table 3). The aforementioned results indicated that the measurements in this study had acceptable validity and reliability. 


\subsection{Structural Model Results}

The analysis of moment structure and structural equation modeling were performed to test the research hypotheses. The structural modeling results are presented in Figure 3. According to the results, the full model had an acceptable fit $(\mathrm{NFI}=0.951, \mathrm{CFI}=0.968, \mathrm{GFI}=0.928$, and RMSEA $=0.061$ ). GSV exhibited direct effects on EGC $(p<0.001$, standardized direct effect $=-0.504)$, EEP $(p<0.01$, standardized direct effect $=0.148$; Figure 3$)$, and GPPO $(p<0.001$, standardized direct effect $=0.426)$. GPPO exhibited direct effects on EGC $(p<0.001$, standardized direct effect $=-0.37)$ and EEP $(p<0.001$, standardized direct effect $=0.452)$. Moreover, EGC exhibited a direct effect on EEP $(p<0.001$, standardized direct effect $=-0.307)$. The study results indicated that $\mathrm{H}_{1}, \mathrm{H}_{3}, \mathrm{H}_{4}, \mathrm{H}_{5}$, and $\mathrm{H}_{7}$ were supported. Thus, GSV has a direct and positive effect on GPPO, EGC, and EEP. GPPO has a direct and significant relationship with EGC and EEP, and EGC has a direct effect on EEP. According to Baron and Kenny [91], who verified the mediating effects, GPPO partially mediates the relationships of GSV with EGC and EEP.

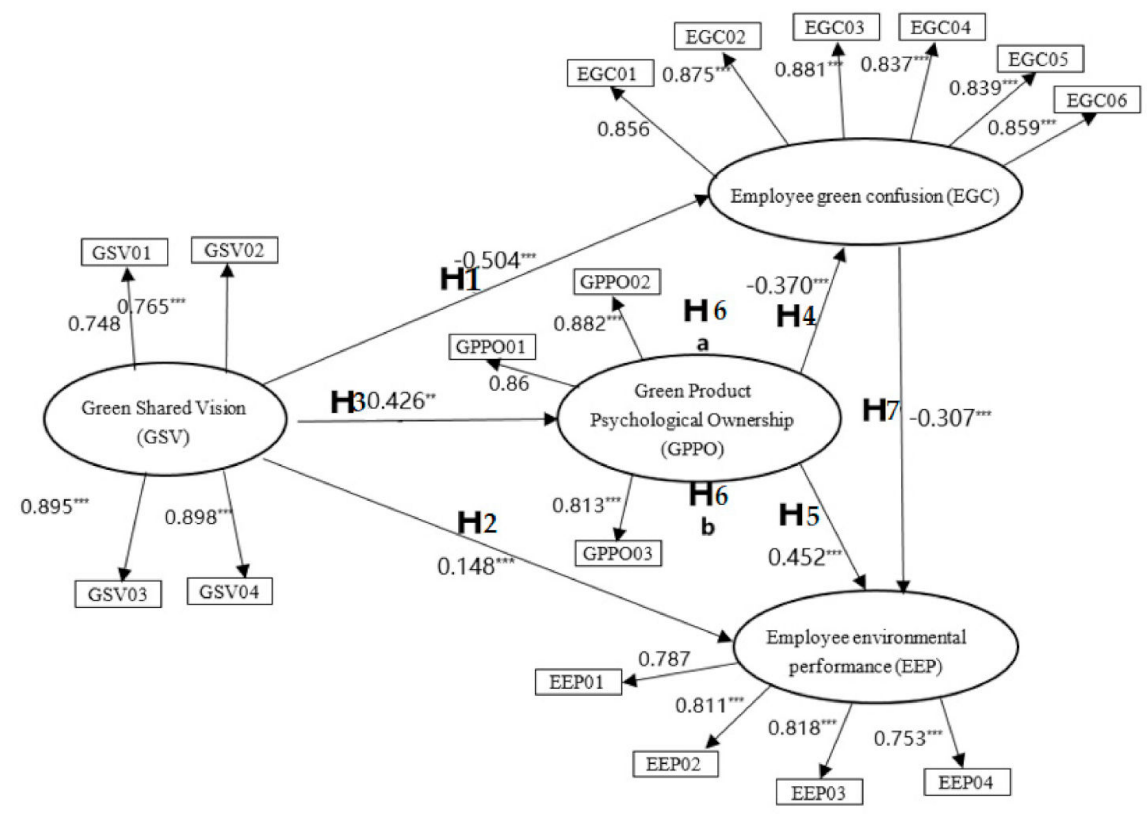
Chi-square $/ \mathrm{df}=2.764, \mathrm{GFI}=0.928$, RMSEA $=0.061, \mathrm{NFI}=0.951$, and $\mathrm{CFI}=0.968$
Note: $p<0.01$, and ${ }^{* * 4 * 4} p<0.001$.

Figure 3. Full model results.

To ensure preciseness, we performed a percentile bootstrap procedure and a deviation correction percentile bootstrap procedure 5000 times with a $95 \%$ confidence interval to examine two mediating models [92]. According to the advice of Preacher and Hayes [93], we calculated the confidence interval of the upper and lower bounds to verify whether the indirect effects were significant. The bootstrap test results presented in Table 5 indicated that GPPO partially mediated the relationship between GSV and EGC (standard indirect effect $=-0.145, Z=4.394, p<0.001 ; 0$ was not included in the $95 \%$ confidence interval) and between GSV and EEP (standard indirect effect $=0.141, Z=4.7, p<0.001$; 0 was not included in the $95 \%$ confidence interval). Thus, hypotheses $6 \mathrm{a}$ and $6 \mathrm{~b}$ were confirmed. After exploring the indirect effects of the variables of the structural model, we further examined the obtained data and found two unexpected intermediary relationships: (1) the mediation effect of EGC on the relationship between GSV and EEP (standard indirect effect $=0.113, Z=2.216, Z>1.96 ; 0$ is not included in the $95 \%$ confidence interval) and (2) the distal mediation effects: GSV and EEP via GPPO and EGC (standard indirect effect $=0.145, Z=1.986, Z>1.96 ; 0$ was not included in the $95 \%$ confidence 
interval). These unexpected results provided a preliminary understanding of the relationship between GSV and EEP. The aforementioned results indicate that enterprise GSV can significantly affect EGC and EEP through GPPO.

Table 5. Mediation results of GPPO and EGC when using a confidence interval bootstrap.

\begin{tabular}{|c|c|c|c|c|c|c|c|}
\hline \multirow{3}{*}{ Path } & \multirow{3}{*}{$\begin{array}{c}\text { Point } \\
\text { Estimation }\end{array}$} & \multirow{2}{*}{\multicolumn{2}{|c|}{ Product of Coefficients }} & \multicolumn{4}{|c|}{ Bootstrapping } \\
\hline & & & & \multicolumn{2}{|c|}{ Bias-Corrected 95\% CI } & \multicolumn{2}{|c|}{ Percentile $95 \%$ CI } \\
\hline & & S.E. & $\mathrm{Z}$ & Lower & Upper & Lower & Upper \\
\hline \multicolumn{8}{|c|}{ Indirect Effects } \\
\hline (1) GSV $\rightarrow$ GPPO $\rightarrow$ EGC & -0.145 & 0.033 & $4.394^{* * *}$ & -0.226 & -0.093 & -0.217 & -0.087 \\
\hline (2) GSV $\rightarrow$ GPPO $\rightarrow$ EEP & 0.141 & 0.030 & $4.7^{* * *}$ & 0.089 & 0.206 & 0.088 & 0.204 \\
\hline (3) GSV $\rightarrow$ EGC $\rightarrow$ EEP & 0.113 & 0.051 & $2.216^{*}$ & 0.036 & 0.242 & 0.031 & 0.230 \\
\hline (4) GSV $\rightarrow$ GPPO $\rightarrow$ EGC $\rightarrow$ EEP & 0.035 & 0.015 & $2.333^{*}$ & 0.013 & 0.075 & 0.010 & 0.069 \\
\hline Total $(1+2+3+4)$ & 0.145 & 0.073 & $1.986^{*}$ & 0.029 & 0.323 & 0.023 & 0.309 \\
\hline \multicolumn{8}{|c|}{ Contrasts } \\
\hline$(1)-(2)$ & 0.027 & 0.063 & 0.429 & -0.105 & 0.145 & -0.102 & 0.150 \\
\hline$(2)-(3)$ & 0.078 & 0.043 & 1.814 & 0.020 & 0.196 & 0.016 & 0.182 \\
\hline (3)-(1) & -0.105 & 0.035 & $3^{* *}$ & -0.105 & -0.181 & -0.182 & -0.040 \\
\hline
\end{tabular}

Notes: (1) Standardized estimation of 5000 bootstrap samples; (2) Contrasts: differences in the two indirect effects; (3) GSV = green shared vision, GPPO = green product psychological ownership, EGC = employee green confusion, and EEP = employee environmental performance; $(4)^{* * *}: Z>3.29,{ }^{* *}: Z>2.58$, and *: $Z>1.96$; and (5) $N=475$.

The full model results are also presented in Table 6. The study results supported all the research hypotheses. The promotion of GSV can reduce EGC and increase EEP through GPPO. Moreover, we verified that GSV has a significant effect on EGC and EEP, and that GPPO has a partial intermediary effect between GSV to EGC and EEP. Therefore, we recommend that companies perform GSV formulation and upgrade GPPO not only to answer the doubts of green employees but also to improve EEP and reduce EGC.

Table 6. Results of the structural model.

\begin{tabular}{|c|c|c|c|c|}
\hline Hypothesis & Path & Path Coefficient & Z Value & Results \\
\hline H1 & $\mathrm{GSV} \rightarrow \mathrm{GPPO}$ & $0.426^{* * *}$ & & H1 is supported \\
\hline $\mathrm{H} 2$ & $\mathrm{GSV} \rightarrow \mathrm{EGC}$ & $-0.504 * * *$ & & $\mathrm{H} 2$ is supported \\
\hline H3 & $\mathrm{GSV} \rightarrow \mathrm{EEP}$ & $0.148^{* *}$ & & $\mathrm{H} 3$ is supported \\
\hline $\mathrm{H} 4$ & $\mathrm{GPPO} \rightarrow \mathrm{EGC}$ & $-0.370 * * *$ & & $\mathrm{H} 4$ is supported \\
\hline H5 & $\mathrm{GPPO} \rightarrow \mathrm{EEP}$ & $0.452 * * *$ & & $\mathrm{H} 5$ is supported \\
\hline H6a & $\mathrm{GSV} \rightarrow \mathrm{GPPO} \rightarrow \mathrm{EGC}$ & & 4.394 \#\# & H6a is supported (partial mediating) \\
\hline $\mathrm{H} 6 \mathrm{~b}$ & $\mathrm{GSV} \rightarrow \mathrm{GPPO} \rightarrow \mathrm{EEP}$ & & $4.7^{\# \# \#}$ & H6b is supported (partial mediating) \\
\hline $\mathrm{H} 7$ & $\mathrm{EGC} \rightarrow \mathrm{EEP}$ & $-0.307^{* * *}$ & & H7 is supported \\
\hline Study found & $\mathrm{GSV} \rightarrow \mathrm{EGC} \rightarrow \mathrm{EEP}$ & & $2.216 \#$ & partial mediating \\
\hline
\end{tabular}

\section{Conclusions and Implications}

In this study, we investigated Taiwanese companies that engage in environmental protection. We examined the effect of psychological processes related to green issues on employees' green management performance. This study verified the relationships among GSV, EEP, GPPO, and EGC through PO theory and expectancy-valence theory. By investigating GSV and the PO of green products, we came to understand the effect of psychological processes related to green issues. Green management performance is enhanced by reducing EGC and improving EEP.

The study results indicate the existence of associations in the concept of integration. For example, the psychological processes related to green issues affect EGC and EEP. In addition, this study indicates that the antecedents of PO strengthen the PO effect as well as the behaviors and attitudes of the parties. The combined insights obtained from PO theory and expected value theory can contribute to sustainable environmental development. The results indicate that GSV has a significant negative correlation with EGC and a significant positive correlation with EEP. Thus, developing a GSV for an enterprise is an important strategy for the enterprise to achieve sustainable development. GSV can strengthen the PO 
of company members; encourage them to work harder to achieve the organization goals; minimize their doubts regarding the environmental policies, specifications, products, and other related information of the company; and improve their environmental performance. To achieve corporate sustainability, a company must strengthen its members' GPPO and formulate a clear corporate GSV. The findings of this study have several theoretical implications.

\subsection{Theoretical Implications}

Our research provides three academic contributions to the sustainable development of green management in the field of psychology. First, the empirical results verified the hypothesis that expectancy-valence theory incorporates PO. When results meet people's expectations, they receive additional investment and compensation, strengthening the PO's degree $[49,94]$. The aforementioned contribution expands the original expected value theory to fields such as topic teaching and learning for young children [94-97], unemployment issues [47,98], and physical and mental health issues [99], which enables research gaps in the field of business management to be filled. Moreover, few studies have examined confusion issues from the perspective of employees. Therefore, this study used the views of PO theory and expectancy-valence theory to establish a research framework for GSV to fill an existing research gap. Second, the empirical results of the past GSV research literature found that GSV contributes to employee's proenvironmental behavior [100], green product development performance [34,101,102], and organizational citizenship behavior for the environment [35], especially focusing on employee behavior and product development performance. Finally, the study results indicate the effect of psychological process related to green issues on green management performance in an integrated conceptual framework. The expectation value theory and PO theory indicate that relationships exist among GSV, GPPO, EGC, and EEP. This finding expands the contribution of psychology to sustainable environmental development. This study also verified PO theory by examining the mediation effects of EGC and EEP on the relationship between GPPO and GSV. The results indicated that GSV enhances the degree of PO and positively affects GPPO. The research model expands the PO model and indicates that GSV is crucial for the formation of PO, reduces a company's EGC, and improves a company's EEP. Thus, GPPO is critical for corporate sustainability $[35,103]$.

\subsection{Practical Implications}

The research findings can help Taiwanese companies promote environmental sustainability. These findings also provide a reference to other Asian companies seeking to perform green management. The research results indicate that a relationship exists between GSV and GPPO in psychological processes related to green issues. Moreover, the results indicate that an organization's green management performance is affected by its EGC and EEP. This study indicates that EGC and EEP are caused by GSV and GPPO. GSV is positively correlated with EEP, GPPO is negatively correlated with EGC and positively correlated with EEP, and EGC is negatively correlated with EEP. The aforementioned results indicate that psychological processes related to green issues improve an organization's green management performance. We found that employees' EEP is affected by their EGC. Therefore, this study proposes several steps for corporate management to reduce EGC and promote EEP. First, the head of the enterprise management class should formulate a GSV, express the goals and aspirations of the company's sustainable development, and regularly discuss and reflect on the amendments to the GSV. The development of a shared vision for the organization would improve organizational performance and motivate members to work toward organizational goal $[29,42,63,104,105]$. Thus, companies should use psychological processes related to green issues for verifying the execution results and adopt an active GSV strategy to create employee GPPO in their business models. By using the aforementioned strategy, companies can reduce employees' EGC and improve their EEP. In particular, companies should formulate an environmental development blueprint and develop incentive plans to encourage their employees to participate in the design and production of environmental products. A good practice is for employees to participate in the production process of environmentally friendly 
products or to assist their company in formulating relevant green policies. Second, the results indicate that GPPO influences GSV, EGC, and EEP. Thus, GPPO can be used as an indicator by companies to promote corporate sustainability and improve green performance. Ignoring employees' GPPO may affect their EGC and EEP. Thus, GPPO is a crucial factor affecting the green behavior and performance of employees. When employees establish PO of green products and a psychological relationship with the subject matter of ownership, they exhibit positive attitudes and ideas, demonstrate improved work performance [57], and are more willing to take risks or sacrifice for the ownership [59]. GSV positively affects GPPO. Both are essential factors for enterprises, and we should integrate relevant GSV and GPPO strategies. In particular, corporations should focus on activities such as the development of green environmental strategies, corporate social responsibility activities, energy saving and carbon reduction activities, resource reuse, and the design of green creative training courses. These activities can enhance employees' GSV and GPPO and thus reduce their EGC and enhance their EEP. The presence of GSV and GPPO may drive market change and competitiveness. Although GSV is the key to a company's sustainable development, members' psychology and behaviors must be improved through further management measures to improve their EEP. Third, the study results indicate that the relationship between GSV and GPPO affects the overall green management performance of a company. This finding is useful for company staff, company managers, policymakers, and scholars and can act as a reference for future related research.

\subsection{Limitations and Future Research}

This study has certain limitations. First, the data analysis results unexpectedly revealed that EGC has a partial mediating effect on the relationship between GSV and EEP. The findings of this study provide preliminary concepts that should be verified using relevant studies. Second, this study analyzes the perspectives of expected value theory and psychological ownership theory and discusses the environmental behavior and performance of organizational employees. Future research can go further and use other theories. For example, the value theory can further strengthen the relationship between Psychological Processes of Green Issues and Green Management Performance through the exploration of Costs and benefits or the expectancy theory. Third, all the research participants were from Taiwan. The universality of the study results may be limited by differences in the national conditions, cultures, industrial scenarios, and economic structures between different countries. Therefore, the results of this study can be verified by conducting research in other countries and regions, such as Singapore, Japan, and South Korea. Finally, from the perspective of the company's internal green management strategy, this study verifies that the psychological processes of company members related to green issues affect their GSV and GPPO. We also analyzed members' environmental behavior and performance as well as excluding other behaviors and organizational characteristics that may disturb employees. In future research, we will be able to further explore the perceived organization's support to the environment and the organization's impact on the environment's citizenship behavior [46]. Or, according to Chen, Chang, and Lin [24], starting from the green absorptive capacity of employees, further discuss the issues and determinants that affect employees' environmental behavior and performance.

\subsection{Conclusions}

According to expectancy-valence theory, the psychological process related to green issues affect the background factors controlling the influence of GSV on company members. This study combined insights from $\mathrm{PO}$ theory and expectancy-valence theory and presented a psychological process structure. Due to the research gap related to the association between GSV and green management scope, this paper presents a framework that emphasizes how GSV affects the relationship between EGC and EEP through GPPO in the current environmental era. This research explored an extramental mechanism that illustrated the connection between GPPO and relevant variables. The research model indicates that EGC and EEP are affected by the exposure to GSV through an increase in GPPO. A Taiwanese employee sample was used to support the proposed hypotheses. This study provides many important 
implications for guiding managers and decision-making authorities. According to the integrated model of the psychological process of green issues in this study, the assumptions of expected value theory and psychological ownership theory indicate the psychological process of employees' motivation and psychological ownership. The overall process of an enterprise to effectively strengthen employees' mentality of green issues is an important key to improving the organization's green management performance. In the process of improving EEP, companies must not only strengthen the psychological process of employees' green issues, but reducing EGC is also an important key. Effectively reducing EGC can enable employees to devote themselves to work and contribute to EEP. Therefore, companies should upgrade their GSV to enhance their employees' GPPO and EEP and decrease their employees' EGC to achieve corporate sustainability goals.

Author Contributions: Conceptualization, T.-W.C.; Data curation, T.-W.C.; Formal analysis, T.-W.C.; Funding acquisition, T.-W.C.; Methodology, T.-W.C.; Resources, T.-W.C.; Writing—review and editing, K.-H.W. and Y.-H.L. All authors have read and agreed to the published version of the manuscript.

Funding: This research was funded by Ministry of Science and Technology, Taiwan: MOST 107-2410-H-606-002.

Conflicts of Interest: The authors declare no conflict of interest.

\section{Appendix A}

Table A1. Survey items of the constructs.

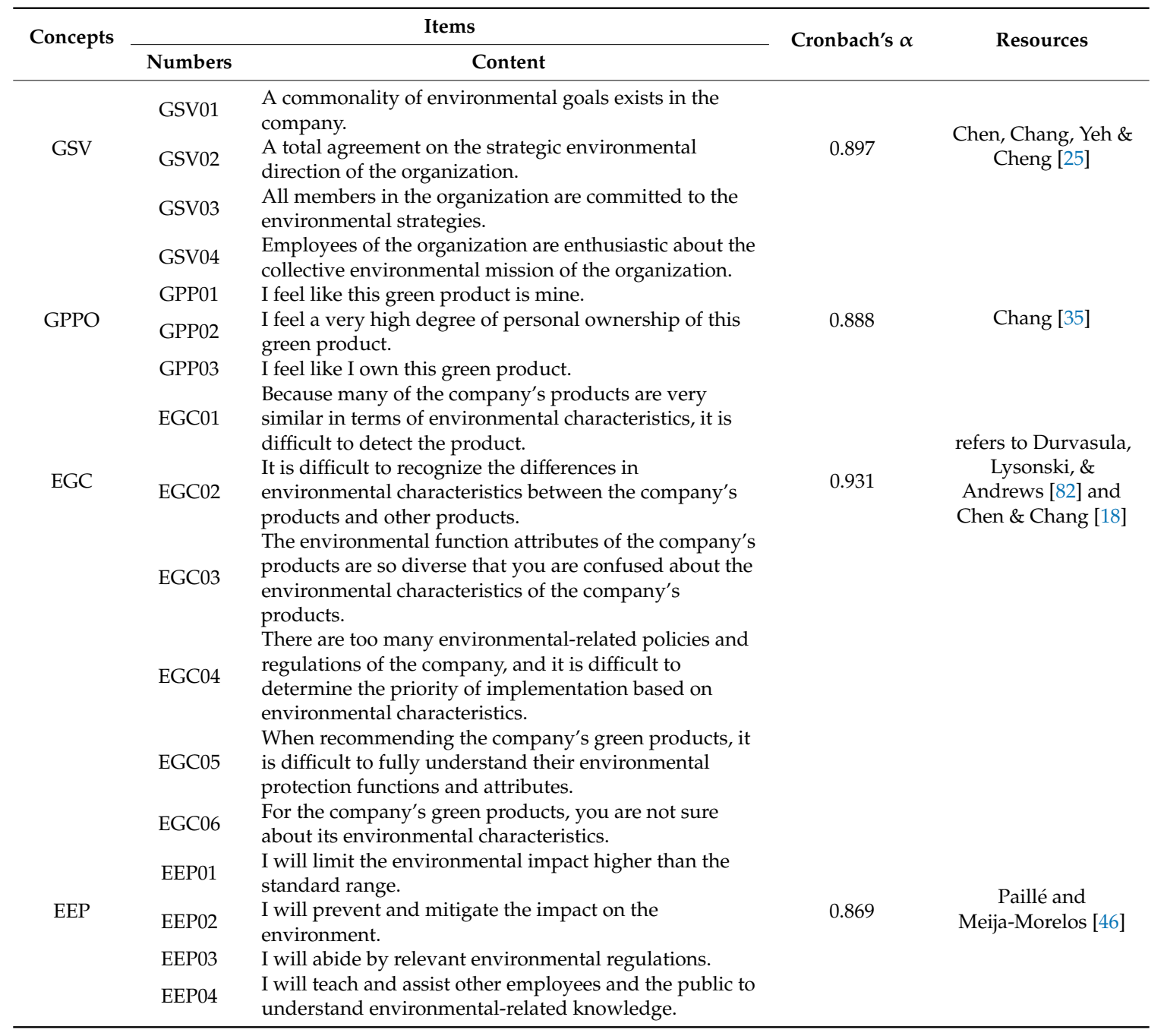




\section{References}

1. Chen, Y.S.; Chang, K.C. The nonlinear effect of green innovation on the corporate competitive advantage. Qual. Quant. 2013, 47, 271-286. [CrossRef]

2. Teng, M.J. The effects of an environmental management system on intangible assets and corporate value: Evidence from Taiwan's manufacturing firms. Asian Bus. Manag. 2011, 10, 381-404. [CrossRef]

3. Chen, Y.S.; Chang, C.H. Enhance green purchase intentions: The roles of green perceived value, green perceived risk, and green trust. Manag. Decis. 2012, 50, 502-520. [CrossRef]

4. Chen, Y.S. The drivers of green brand equity: Green brand image, green satisfaction, and green trust. J. Bus. Ethics 2010, 93, 307-319. [CrossRef]

5. Boyatzis, R.E.; Rochford, K.; Taylor, S.N. The role of the positive emotional attractor in vision and shared vision: Toward effective leadership, relationships, and engagement. Front. Psychol. 2015, 6, 670-683. [CrossRef]

6. Senbel, M. Leadership in sustainability planning: Propagating visions through empathic communication. J. Environ. Plan. Manag. 2015, 58, 464-481. [CrossRef]

7. Chen, C.H. Effects of shared vision and integrations on entrepreneurial performance: Empirical analyses of 246 new Chinese ventures. Chin. Manag. Stud. 2015, 9, 150-175.

8. Davenport, M.; Delport, M.; Blignaut, J.N.; Hichert, T.; Van der Burgh, G. Combining theory and wisdom in pragmatic, scenario-based decision support for sustainable development. J. Environ. Plan. Manag. 2019, 62, 692-716. [CrossRef]

9. Ball, D.R. A Technology, Innovation, and Operations Strategic Model for Both Domestic and Global Sustainability. Int. J. Sustain. Soc. 2010, 5, 485-491.

10. Corbett, L.M. Sustainable operations management: A typological approach. J. Ind. Eng. Manag. 2009, 2, 10-30. [CrossRef]

11. Preston, L. Sustainability at Hewlett-Packard: From theory to practice. Calif. Manag. Rev. 2001, 43, $26-37$. [CrossRef]

12. Lozano, R. A holistic perspective on corporate sustainability drivers. Corp. Soc. Responsib. Environ. Manag. 2015, 22, 32-44. [CrossRef]

13. Muradli, R.; Volkova, T. Strategic innovation application in creative industries in latvia. J. Bus. Manag. 2015, 10, 15-27.

14. Avota, S.; McFadzean, E.; Peiseniece, L. Linking personal and organisational values and behaviour to corporate sustainability: A conceptual model. J. Bus. Manag. 2015, 10, 124-138.

15. Drucker, P.F. The Practice of Management; Harper \& Row: New York, NY, USA, 1954.

16. Pfeffer, J. Competitive Advantage Through People: Unleashing the Power of the Work Force; HBS Press: Boston, MA, USA, 1994.

17. Chuai, X.; Preece, D.; Iles, P. Is talent management just old wine in new bottles? Manag. Res. News 2008, 31, 901-911. [CrossRef]

18. Chen, Y.S.; Chang, C.H. Greenwash and green trust: The mediation effects of green consumer confusion and green perceived risk. J. Bus. Ethics 2013, 114, 489-500. [CrossRef]

19. Szabo, S.; Webster, J. Perceived Greenwashing: The Effects of Green Marketing on Environmental and Product Perceptions. J. Bus. Ethics 2020, 1-21. [CrossRef]

20. Chen, Y.S. The positive effect of green intellectual capital on competitive advantages of firms. J. Bus. Ethics 2008, 77, 271-286. [CrossRef]

21. Chen, Y.S.; Chang, C.H. The determinants of green product development performance: Green dynamic capabilities, green transformational leadership, and green creativity. J. Bus. Ethics 2013, 116, 107-119. [CrossRef]

22. Chen, Y.S.; Chang, C.H. Enhance environmental commitments and green intangible assets toward green competitive advantages: An analysis of structural equation modeling (SEM). Qual. Quant. 2013, 47, 529-543. [CrossRef]

23. Yeh, S.L.; Chen, Y.S.; Wu, S.S. The Obstacles and Solutions to the Corporate Social Responsibility Implementation in Taiwan. Int. J. Innov. Manag. Technol. 2014, 5, 266. [CrossRef] 
24. Chen, Y.S.; Chang, C.H.; Lin, Y.H. The determinants of green radical and incremental innovation performance: Green shared vision, green absorptive capacity, and green organizational ambidexterity. Sustainability 2014, 6, 7787-7806. [CrossRef]

25. Chen, Y.S.; Chang, C.H.; Yeh, S.L.; Cheng, H.I. Green shared vision and green creativity: The mediation roles of green mindfulness and green self-efficacy. Qual. Quant. 2015, 49, 1169-1184. [CrossRef]

26. Chen, Y.S.; Huang, A.F.; Wang, T.Y.; Chen, Y.R. Greenwash and green purchase behaviour: The mediation of green brand image and green brand loyalty. Total Qual. Manag. Bus. Excell. 2018, 1-16. [CrossRef]

27. Dowling, J.; Pfeffer, J. Organizational legitimacy: Social values and organizational behavior. Pac. Sociol. Rev. 1975, 18, 122-136. [CrossRef]

28. Ashforth, B.E.; Gibbs, B.W. The double-edge of organizational legitimation. Organ. Sci. 1990, 1, $177-194$. [CrossRef]

29. Larwood, L.; Falbe, C.M.; Kriger, M.P.; Miesing, P. Structure and meaning of organizational vision. Acad. Manag. J. 1995, 38, 740-769.

30. Sosik, J.J.; Kahai, S.S.; Avolio, B.J. Transformational leadership and dimensions of creativity: Motivating idea generation in computer-mediated groups. Creat. Res. J. 1998, 11, 111-121. [CrossRef]

31. Bart, C.K.; Hupfer, M. Mission statements in Canadian hospitals. J. Health Organ. Manag. 2004, 18, 92-110. [CrossRef]

32. Mitchell, V.-W.; Walsh, G.; Yamin, M. Towards a conceptual model of consumer confusion. Adv. Consum. Res. 2005, 32, 143-150.

33. Leek, S.; Chansawatkit, S. Consumer confusion in the thai mobile phone market. J. Consum. Behav. 2006, 5, 518-532. [CrossRef]

34. Chang, T.W.; Chen, F.F.; Luan, H.D.; Chen, Y.S. Effect of green organizational identity, green shared vision, and organizational citizenship behavior for the environment on green product development performance. Sustainability 2019, 11, 617. [CrossRef]

35. Chang, T.W. Corporate Sustainable Development Strategy: Effect of Green Shared Vision on Organization Members' Behavior. Int. J. Environ. Res. Public Health 2020, 17, 2446. [CrossRef]

36. Bart, C.K.; Tabone, J.C. Mission statement rationales and organizational alignment in the not-for-profit health care sector. Health Care Manag. Rev. 1998, 23, 54-69. [CrossRef]

37. Henriques, I.; Sadorsky, P. The relationship between environmental commitment and managerial perceptions of stakeholder importance. Acad. Manag. J. 1999, 42, 87-99.

38. Hart, S.L. A natural-resource-based view of the firm. Acad. Manag. Rev. 1995, 20, 986-1014. [CrossRef]

39. Alt, E.; Díez-de-Castro, E.P.; Lloréns-Montes, F.J. Linking employee stakeholders to environmental performance: The role of proactive environmental strategies and shared vision. J. Bus. Ethics 2015, 128, 167-181. [CrossRef]

40. Brewer, M.B.; Miller, N. Beyond the Contact Hypothesis: Theoretical Perspectives on Desegregation. In The Psychology of Desegregation; Miller, N., Brewer, M.B., Eds.; Academic Press: New York, NY, USA, 1984.

41. Mackie, D.M.; Goethals, G.R. Individual and Group Goals. In Review of Personality and Social Psychology; Hendrick, C., Ed.; Sage: Newbury Park, CA, USA, 1987.

42. Hofhuis, J.; Mensen, M.; ten Den, L.M.; van den Berg, A.M.; Koopman-Draijer, M.; van Tilburg, M.C.; de Vries, S. Does functional diversity increase effectiveness of community care teams? The moderating role of shared vision, interaction frequency, and team reflexivity. J. Appl. Soc. Psychol. 2018, 48, 535-547. [CrossRef]

43. Yen, Y.X.; Yen, S.Y. Top-management's role in adopting green purchasing standards in high-tech industrial firms. J. Bus. Res. 2012, 65, 951-959. [CrossRef]

44. Rivera-Camino, J. Corporate environmental market responsiveness: A model of individual and organizational drivers. J. Bus. Res. 2012, 65, 402-411. [CrossRef]

45. Paillé, P.; Raineri, N. Linking perceived corporate environmental policies and employees eco-initiatives: The influence of perceived organizational support and psychological contract breach. J. Bus. Res. 2015, 68, 2404-2411. [CrossRef]

46. Paillé, P.; Meija-Morelos, J.H. Organisational support is not always enough to encourage employee environmental performance. The moderating role of exchange ideology. J. Clean. Prod. 2019, 220, 1061-1070. [CrossRef] 
47. Vansteenkiste, V.; Lens, W.; De Witte, H.; Feather, N.T. Understanding unemployed people's job search behaviour, unemployment experience and well-being: A comparison of expectancy-value theory and self-determination theory. Br. J. Soc. Psychol. 2005, 44, 269-287. [CrossRef] [PubMed]

48. Eccles, J.S.; Adler, T.F.; Futterman, R.; Goff, S.B.; Kaczala, C.M.; Meece, J.L.; Spence, J.T. Achievement and achievement motivation. Expect. Values Acad. Behav. 1983, 8, 75-146.

49. Vroom, V.H. Work and Motivation; Wiley: New York, NY, USA, 1964.

50. Saeed, B.B.; Afsar, B.; Hafeez, S.; Khan, I.; Tahir, M.; Afridi, M.A. Promoting employee's proenvironmental behavior through green human resource management practices. Corp. Soc. Responsib. Environ. Manag. 2019, 26, 424-438. [CrossRef]

51. Furby, L. Possessions: Toward a theory of their meaning and function throughout the life cycle. Life Span. Dev. Behav. 1978, 1, 297-336.

52. Dittmar, H. The Social Psychology of Material Possessions: To Have Is to Be; St. Martin's Press: New York, NY, USA, 1992.

53. Belk, R.W. Possessions and the extended self. J. Consum. Res. 1998, 15, 139-168. [CrossRef]

54. Isaacs, S. Social development in young children. Br. J. Educ. Psychol. 1993, 3, 291-294. [CrossRef]

55. Kline, L.W.; France, C.J. The psychology of ownership. Pedagog. Semin. 1899, 6, 421-470. [CrossRef]

56. Pierce, J.L.; Rubenfeld, S.A.; Morgan, S. Employee ownership: A conceptual model of process and effects. Acad. Manag. Rev. 1991, 16, 121-144. [CrossRef]

57. Beggan, J.K. On the social nature of nonsocial perception: The mere ownership effect. J. Personal. Soc. Psychol. 1992, 62, 229-237. [CrossRef]

58. Pierce, J.L.; Kostova, T.; Dirks, K.T. Toward a theory of psychological ownership in organizations. Acad. Manag. Rev. 2001, 26, 298-310. [CrossRef]

59. Pierce, J.L.; Kostova, T.; Dirks, K.T. The state of psychological ownership: Integrating and extending a century of research. Rev. Gen. Psychol. 2003, 7, 84-107. [CrossRef]

60. Pierce, J.L.; Jussila, I. Psychological Ownership and the Organizational Context: Theory, Research Evidence, and Application; Edward Elgar Publishing: Cheltenham, UK, 2011.

61. Jussila, I.; Tarkiainen, A.; Sarstedt, M.; Hair, J.F. Individual psychological ownership: Concepts, evidence, and implications for research in marketing. J. Mark. Theory Pract. 2015, 23, 121-139.

62. Chiu, W.C.K.; Hui, C.H.; Lai, G.W. Psychological ownership and organizational optimism amid China's corporate transformation: Effects of an employee ownership scheme and a management-dominated board. Int. J. Hum. Resour. Manag. 2007, 18, 303-320. [CrossRef]

63. Tsai, W.; Ghoshal, S. Social capital and value creation: The role of intrafirm networks. Acad. Manag. J. 1998, 41, 464-476.

64. Colakoglu, S. Shared vision in MNE subsidiaries: The role of formal, personal, and social control in its development and its impact on subsidiary learning. Thunderbird Int. Bus. Rev. 2012, 54, 639-652. [CrossRef]

65. Nahapiet, J.; Ghoshal, S. Social capital, intellectual capital, and the organizational advantage. Acad. Manag. Rev. 1998, 23, 242-266. [CrossRef]

66. Van Dyne, L.; Pierce, J.L. Psychological ownership and feelings of possession: Three field studies predicting employee attitudes and organizational citizenship behavior. J. Organ. Behav. 2004, 25, 439-459. [CrossRef]

67. Mustafa, M.; Ramos, H.M.; Man, T.W.Y. Linking psychological ownership to employee extra-role behaviours in small overseas Chinese family businesses: Does family status matter? J. Entrep. Emerg. Econ. 2015, 7, 129-147. [CrossRef]

68. Nuttin, J.M., Jr. Affective consequences of mere ownership: The name letter effect in twelve European languages. Eur. J. Soc. Psychol. 1987, 17, 381-402. [CrossRef]

69. Dirks, K.T.; Cummings, L.L.; Picrce, J.L. Psychological Ownership in Organizations: Conditions Under Which Individuals Promote and Resist Change. In Research in or-Ganizational Change and Deuelopment; Woodman, R.W., Pasmore, W.A., Eds.; JAI Press: Greenwich, CT, USA, 1996; Volume 9, pp. 1-24.

70. Vandewalle, D.; Van Dyne, L.; Kostova, T. Psychological ownership: An empirical examination of its consequences. Group Organ. Manag. 1995, 20, 210-226. [CrossRef]

71. Avey, J.B.; Avolio, B.J.; Crossley, C.D.; Luthans, F. Psychological ownership: Theoretical extensions, measurement and relation to work outcomes. J. Organ. Behav. Int. J. Ind. Occup. Organ. Psychol. Behav. 2009, 30, 173-191. [CrossRef] 
72. Peng, H.; Pierce, J. Job-and organization-based psychological ownership: Relationship and outcomes. J. Manag. Psychol. 2015, 30, 151-168. [CrossRef]

73. Wilpert, B. Property, Ownership, and Participation: On the Growing Contradictions Between Legal and Psychological Concepts. In International Handbook of Participation in Organizations: For the Study of Organizational Democracy, Coo-Operation, and Self-Management; Russell, R., Rus, V., Eds.; Oxford University Press: New York, NY, USA, 1991; Volume 2, pp. 149-164.

74. Shrivastava, P.; Hart, S. Greening organizations. Acad. Manag. Proc. 1992, 1, 185-189. [CrossRef]

75. Peattie, K. Green Marketing; Pitman Publishing: London, UK, 1992.

76. Kirchgeorg, M. Okologieorientieres Unternehmensverhalten. In Typologien und Erklarungsasatze anfempirischer Gundlage; Gabler: Wieshaden, Germany, 1990.

77. Ramus, C.A.; Steger, U. Organizational Support for Employees: Encouraging Creative Ideas for Environmental Sustainability. Calif. Manag. Rev. 2001, 43, 85-105. [CrossRef]

78. Shrivastava, P. Castrated Environment: Greening Organizational Studies. Organ. Stud. 1994, 15, 705-726. [CrossRef]

79. Porter, M.E.; van der, L. Green and Competitive. Harv. Bus. Rev. 1995, 73, 120-134.

80. MacKenzie, S.B.; Podsakoff, P.M. Common method bias in marketing: Causes, mechanisms, and procedural remedies. J. Retail. 2012, 88, 542-555. [CrossRef]

81. Cacioppo, J.T.; Petty, R.E. The need for cognition. J. Personal. Soc. Psychol. 1982, 42, 116-131. [CrossRef]

82. Durvasula, S.; Lysonski, S.; Andrews, J.C. Cross-cultural generalizability of a scale for profiling consumers' decision-making styles. J. Consum. Aff. 1993, 27, 55-65. [CrossRef]

83. Kaiser, H.F. The varimax criterion for analytic rotation in factor analysis. Psychometrika 1958, 23, $187-200$. [CrossRef]

84. Nunnally, J.C.; Bernstein, I.H. Psychometric Theory; McGraw-Hill: London, UK, 1978.

85. Hair, J.F.; Anderson, R.E.; Tatham, R.L.; Black, W.C. Multivariate Data Analysis; Prentice-Hall, Inc.: Upper Saddle River, NJ, USA, 1998.

86. Williams, L.J.; Hazer, J.T. Antecedents and consequences of satisfaction and commitment in turnover models: A reanalysis using latent variable structural equation methods. J. Appl. Psychol. 1986, 71, 219. [CrossRef]

87. Anderson, J.C.; Gerbing, D.W. Structural equation modeling in practice: A review and recommended two-step approach. Psychol. Bull. 1988, 103, 411. [CrossRef]

88. Fornell, C.; Larcker, D.F. Evaluating structural equation models with unobservable variables and measurement error. J. Mark. Res. 1981, 18, 39-50. [CrossRef]

89. Henseler, J.; Ringle, C.M.; Sarstedt, M. A new criterion for assessing discriminant validity in variance-based structural equation modeling. J. Acad. Mark. Sci. 2015, 43, 115-135. [CrossRef]

90. Bagozzi, R.P.; Yi, Y. On the evaluation of structural equation models. J. Acad. Mark. Sci. 1988, 16, 74-94. [CrossRef]

91. Baron, R.M.; Kenny, D.A. The moderator-mediator variable distinction in social psychological research: Conceptual, strategic, and statistical considerations. J. Personal. Soc. Psychol. 1986, 51, 1173-1182. [CrossRef]

92. Taylor, A.B.; MacKinnon, D.P.; Tein, J.Y. Tests of the three-path mediated effect. Organ. Res. Methods 2008, 11, 241-269. [CrossRef]

93. Preacher, K.J.; Hayes, A.F. Asymptotic and resampling strategies for assessing and comparing indirect effects in multiple mediator models. Behav. Res. Methods 2008, 40, 879-891. [CrossRef]

94. Wigfield, A.; Eccles, J.S. Expectancy-value theory of achievement motivation. Contemp. Educ. Psychol. 2000, 25, 68-81. [CrossRef] [PubMed]

95. Poort, I.; Jansen, E.; Hofman, A. Intercultural group work in higher education: Costs and benefits from an expectancy-value theory perspective. Int. J. Educ. Res. 2019, 93, 218-231. [CrossRef]

96. Hong, W.Z. Exploring the Effects of Intrinsic Motive, Utilitarian Motive, and Self-Efficacy on Students' Science Learning in the Classroom Using the Expectancy-Value Theory. Res. Sci. Educ. 2019, 1-13. [CrossRef]

97. Wigfield, A. Expectancy-value theory of achievement motivation: A developmental perspective. Educ. Psychol. Rev. 1994, 6, 49-78. [CrossRef]

98. Feather, N.T. Expectancy-value theory and unemployment effects. J. Occup. Organ. Psychol. 1992, 65, 315-330. [CrossRef]

99. Shepperd, J.A. Social Loafing and Expectancy-Value Theory. In Multiple Perspectives on the Effects of Evaluation on Performance; Springer: Boston, MA, USA, 2001; pp. 1-24. 
100. Afsar, B.; Maqsoom, A.; Shahjehan, A.; Afridi, S.A.; Nawaz, A.; Fazliani, H. Responsible leadership and employee's proenvironmental behavior: The role of organizational commitment, green shared vision, and internal environmental locus of control. Corp. Soc. Responsib. Environ. Manag. 2020, 27, 297-312. [CrossRef]

101. Chen, Y.S.; Lin, S.H.; Lin, C.Y.; Hung, S.T.; Chang, C.W.; Huang, C.W. Improving green product development performance from green vision and organizational culture perspectives. Corp. Soc. Responsib. Environ. Manag. 2020, 27, 222-231. [CrossRef]

102. Chang, T.W.; Yeh, Y.L.; Li, H.X. How to Shape an Organization's Sustainable Green Management Performance: The Mediation Effect of Environmental Corporate Social Responsibility. Sustainability 2020, 12, 9198. [CrossRef]

103. Chang, T.W.; Chen, Y.S.; Yeh, Y.L.; Li, H.X. Sustainable consumption models for customers: Investigating the significant antecedents of green purchase behavior from the perspective of information asymmetry. J. Environ. Plan. Manag. 2020, 1-21. [CrossRef]

104. Rieckhoff, B.S.; Larsen, C. The impact of a professional development network on leadership development and school improvement goals school-university partnerships. Sch. Univ. Partnersh. 2012, 5, 57-73.

105. Kotter, J.P. Leading Change; Harvard Business School Press: Boston, MA, USA, 1996.

Publisher's Note: MDPI stays neutral with regard to jurisdictional claims in published maps and institutional affiliations.

(C) 2020 by the authors. Licensee MDPI, Basel, Switzerland. This article is an open access article distributed under the terms and conditions of the Creative Commons Attribution (CC BY) license (http://creativecommons.org/licenses/by/4.0/). 